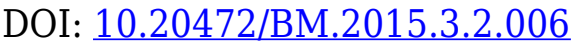

\title{
MARKETING TO MULTICULTURAL AUDIENCES - ETHNIC MARKETING FOR TURKS IN THE GERMAN AUTOMOTIVE AND TELECOMMUNICATIONS INDUSTRIES
}

\author{
PATRICK SZILLAT, ALEXANDER BETOV
}

\begin{abstract}
:
Purpose - This research paper sheds light on the chances and risks for German enterprises aiming to penetrate the sub-culture of the Turkish population in Germany.

Design/methodology/approach - The research paper is based on secondary sources. Both the terminology and the history of ethnic marketing are defined. The potential of Turks in Germany as a target group is analyzed and the best course of action of how to penetrate this group is proposed. Furthermore, the authors give insights into the immigration of Turkish citizens to Germany and the cultural differences resulting from these circumstances. In addition, media use and recommendations for operative marketing and retail practice are given.
\end{abstract}

Outcome and Conclusions - The conclusions show distinct differences with regard to the Turkish and German target group with a focus on cultural aspects. These differences hold major pitfalls for German enterprises targeting the Turkish citizens using operative marketing tools related to sub-cultural patterns.

\section{Keywords:}

ethnic marketing, ethnic groups, multicultural targeting, glocalization, Germany, Turkey

JEL Classification: M00, M31

\section{Authors:}

PATRICK SZILLAT, Poznan University of Economics, Poland, Email: Patrick.Szillat@gmail.com ALEXANDER BETOV, Fontys University of Applied Sciences, Venlo, Netherlands, Email: a.betov@fontys.nl

\section{Citation:}

PATRICK SZILLAT, ALEXANDER BETOV (2015). Marketing to multicultural audiences - Ethnic marketing for Turks in the German automotive and telecommunications industries. International Journal of Business and Management, Vol. III(2), pp. 85-95., 10.20472/BM.2015.3.2.006 


\section{INTRODUCTION}

The multicultural approach towards marketing is important for sustainable success and growth. Since many Western markets are saturated, it becomes important for multinational enterprises (MNEs) to seek either new national markets and/or to try to optimize the penetration of potential multicultural target groups within the current, domestic market. However, immigrant sub-cultures are still hardly penetrated, although they might hold large potential to companies (Erdem \& Schmidt, 2008, p. 212). One tremendously saturated market is the German telecommunications market, with a cell phone saturation of over $100 \%$ and the largest immigrant group in Germany - the Turks.

\section{ACADEMIC APPROACH}

The first step to identifying the concrete potential of a target group and to decide about the best course of action of how to penetrate it is a detailed analysis. Here, the focus is on the demography of the Turkish population living in Germany, focusing on income, education and consumer behaviour. In order to get a deeper understanding of the cultural patterns a modified STEP analysis is implemented. The focus is on social, economic and cultural characteristic patterns of the Turkish population. Analysis of technological and political indicators as well as a detailed internal analysis regarding strengths and weaknesses do not take place, since this paper focuses on the market and the potential target group within.

\section{ETHNIC MARKETING}

\subsection{Definition of ethnic marketing}

Ethnic marketing or intercultural marketing refers to the orientation of marketing activities towards target groups with particular ethnic characteristics. Often, ethnic marketing is referred to as "advertising for immigrants". This misconception was repeatedly the cause of well-intentioned but hastily executed communication measures. Ethnic marketing includes all basic strategic, planning and operational activities focused on ethnic characteristics of the defined target group. Here, the authors offer a correct definitional work-up including both communicative and strategic aspects:

Ethnic marketing is the targeted integration of characteristics of members of ethnic groups in the marketing planning. The aim is a communicative approach to ethnic cultures in consideration of culture, religion, value systems, rituals and symbolism in order to attract new target groups in existing markets (Wilken, 2004, pp. 9-11).

\subsection{History of ethnic marketing approaches in Germany}

In Germany, the origins of ethnic marketing date back to the 1960s and contrary to many assumptions are not found in the consumer goods market but in the area of public broadcasting. The German economy experienced a boom after another, German companies have been very busy and so it became apparent that foreign workers were needed for the accomplishing of the orders. In the 1960s, this resulted in over 120,000 immigrant Italian workers, looking for distraction far away from home. This resulted in the first radio broadcasts specially addressing the target audience of Italian origin. The first trials were of a relatively timid nature as the programme of the West German broadcasting corporation usually did not extend beyond a quarter of an hour. However, the activities in the segment focusing on the entertainment of migrants increasingly gained momentum. This was followed by broadcasts in Greek, Spanish, Turkish and Serbo-Croatian which constantly increased foreign workers' interest in native-language entertainment. At the peak, $50 \%$ of the foreign workers were daily consuming so-called "programmes for foreigners". Monthly, the editors received several thousand letters with valuable suggestions. Thus, the foundation for ethnic marketing 
seemed to be laid. However, it took several decades for German companies to discover this widespread marketing instrument that already was popular in the United States (Bertram, 2006).

\subsection{Ethnic marketing today}

Nowadays, there are relatively few organizations targeting ethnic audiences in Germany. As already mentioned, many organizations are insufficiently informed about the existence of inhomogeneous target groups, or simply ignore the relevance of ethnic characteristics. Looking at the websites of many organizations, it can be noted that most of them offer their content in German and English. Although the German automobile manufacturer BMW ranks among the most popular brands among the buyership of Turkish origin (Schroeder, 2007) BMW's website (BMW Germany, 2015) does not offer the option of switching the display language to Turkish. Also, many other automobile manufacturers do not provide their customers of Turkish origin with information in their native language. Despite the fact that information on the different car models is available on BMW's Turkish domain, access to BMW's distribution network or the German used car market is only granted to Germanspeaking customers.

When analyzing the approach of German mobile phone providers it can be noted that even the current market leader T-Mobile does not provide direct links to its products and services in the Turkish language. Thus, potential customers must use Internet search engines in order to ultimately get to T-Mobile's sub business unit T-Zones. In contrast, the E-Plus subsidiary Ay Yildiz favours a more customer-friendly approach when addressing its Turkish clients. This is discussed in the fifth subchapter with the help of specific examples.

\section{THE TURKISH POPULATION IN GERMANY}

In 2011, the population of citizens with Turkish origin in Germany was estimated to 2.956 million inhabitants (Federal Office for Migration and Refugees, 2013, p. 158). Hence, the Turkish are the largest ethnic community in Germany and hold a great potential from a marketing perspective for German enterprises. To exploit this potential, a careful analysis of this cultural group is indispensable, which is performed in this subchapter.

\subsection{Cultural aspects}

The mentality, values and hierarchical structures of the Turkish population differ fundamentally from classic German conditions. Although a change in the second and third generation of Turkish-born Germans with respect to their consumer behaviour can be noted, this target group still has its distinct and sensitive characteristics that need to be considered by companies.

Native traditions play an important role. The family structure, with the patriarch in a leading position is still intact in the third or fourth generation. Deliberately dominant and masculine appearance and behaviour are internalized by both young German Turks and more mature Turks (Schroeder, 2007). The role of women is less emancipated than it might be assumed in general. Often, a family's male members make the decisions. When buying high involvement goods such as cars it can be assumed that male family members have the sole decision-making power. Even with regard to low involvement products or clearly-marked ladies products companies should consider that in many cases the male family member still makes the buying decision.

Furthermore, this segment of society shows an increased sensitivity with respect to religious values and erotic presentation. In terms of liberality, the social thinking is no longer congruent with the conception of an average German. Also, the need for individuality is less prevalent than in German society. Furthermore, the family plays a far more important role within the set of values. Here, many risks for German companies become apparent. Well- 
intentioned "gadgets" or "give-aways" may offend the mostly Muslim Turks and lead to a rejection of a company's products (Reinnarth, 2007). This shall be discussed in more detail in the last part of chapter four. Additionally, examples of both successful and unfavourable advertisings are given.

\subsection{Monetary potential}

Commonly, the monetary potential behind Turkish customers is underestimated significantly. In many places, the misconception that Turks are very price-conscious consumers who mostly buy Turkish goods at a Turkish retailers. The next two sub-sections will elicit that these allegations seem false.

\subsubsection{Consumer behaviour}

The ethnic group of Turks plays an important role in the German economy. The second and third generations within the Turkish cultural group experienced a change in attitude. While the first two generations came to Germany purely for the purpose of working in the country, most of the persons born in Germany regard Germany as their homeland. The trend of investments and real estate in Turkey turned into a consumer-oriented and free-spending attitude for the benefit of the German economy. Contrary to the common opinion that Turks consume only homeland products, most Turks opt for German products. When comparing the Turkish buying behaviour with the German one it can be noticed that in general the Turks appear as quality conscious shoppers with clear preferences. Here, for instance, every fifth Turk decides to purchase a Mercedes Benz, while only every 18th German makes the same decision (Reinnarth, 2007).

In this context, $38 \%$ of German Turks think that a product's quality is more important than its price. Accordingly, 38\% believe that brand products need to be priced higher. Also, the Turkish preference for their mother tongue can be observed in this target group's great interest in their native media - about $83 \%$ use Turkish newspapers and TV channels such as TRT INT. Thus, already many non-Turkish companies use these media as advertising platforms. BMW, Commerzbank, Deutsche Bank, E-Plus, Germanwings, Haribo, HypoVereinsbank, Kentucky Fried Chicken, OBI, Seat, SunExpress, Vodafone, VW and Western Union Bank rank among them (German-Turkish News, 2013).

In addition, the brand affinity within this ethnic group tends to be higher than within the German population; the awareness of many brands is even higher within the Turkish community than within the German one. Particularly prestigious consumer goods such as jewelry, fashion goods and technical products enjoy great popularity. Understatement is of little relevance because within the Turkish cultural group it is not considered as negative to show ones material possessions and monetary wealth openly (Reinnarth, 2007).

However, it is important that despite their preference for German brands Turks put special emphasis on counselling in the Turkish language when buying high-priced high-involvement goods and services. A study of Emnid, one of Germany's largest opinion research institutes, shows that with regard to the general conclusion of contracts $72.7 \%$ of the respondents regard counseling in their native language as "Very important". The situation is similar regarding the conclusion of insurances $(71.0 \%)$ and banking (68.3\%).

\subsubsection{Earning capacity}

In 2007, the target group of Turkish origin had an estimated cash capital of 62 billion euros. This considerable amount can be traced back to the previously-mentioned first and second generation of immigrants that were planning to move back to Turkey with their saved capital. However, many people did not succeed in achieving this goal for many different reasons and thus today's generation of heirs has considerably more money for consumption as the generations of their parents or grandparents. Approximately, $70 \%$ of all Turks in Germany have a household income of $1.000-3.000$ Euros per month and thus average income of roughly 2.000 euros per month (Struening, 2012). The relatively low savings rate of $450 €$ monthly is important for German companies that want to benefit from this target group as 
now the Turks have more than 1500 euros for consumption at their disposal. If you carry out a projection it becomes clear that the annual net income of the people of Turkish origin amounts to 14 billion euros. This results in more than 10 billion euros consumer spending, which, as already mentioned, mostly is made in Germany. The total Turkish savings rate is about 3 billion euros, which also might inure to the benefit of the German economy, as usually the saved capital is used to buy real estate or automobiles.

\section{ETHNIC MARKETING CAMPAIGNS FOR TURKS IN GERMANY}

Mercedes-Benz was the first company to identify Turkish consumers as an exciting target group in Germany. As early as in the beginning of the 1980s, Turks were the ideal target group for the automobile manufacturer as for each fifth Turk was driving a Mercedes. Since the mid-1990s, the German company relied on the power of the personal attention and contact with the Turkish clientele and thus employed Turkish sales consultants in regions with a high proportion of Turkish inhabitants. In some locations with a high share of Turkish customers tea was served and strong emphasis was put on creating the right atmosphere (Sassy, 2008, p. 38).

However, this behaviour may be due to Mercedes' Turkish advertising slogan "MercedesBenz, her zaman iyidir" - "Mercedes Benz is always good", which is used in Turkish media (Sassy, 2008, p. 38).The campaigns were supported by Turkish-speaking hotlines and call centres. With the help of these instruments the company increased its sales from 8 to 13 percent. Here, the advertising focus was on TV spots supported by print ads. The introduction of Mercedes' V-Class, offered Mercedes the possibility of direct targeting, since this car model is almost tailor-made for Turkish commercial companies, which often are family businesses (Sassy, 2008, p. 38).

"Wer die Familie nicht ehrt, verdient mit Türken kein Geld." (If you don't honour the family, you cannot make money with Turks)

Almost exemplary, Mercedes took this slogan into practice in its Turkish advertising for the VClass. Here, a Turkish three-generation family is shown in emotional angles and shots around the V-Class. A girl who tells about her family members and their relation and attitude towards the V-Class and thus demonstrates the advantages of the car takes centre stage. The girl is wearing a red dress which symbolizes the Turkish national colour. Furthermore, in several shots you see a "magic eye", a Turkish talisman. The car's licence plates feature the letters $\mathrm{E}$ and $\mathrm{V}$, which together make up the Turkish word for home and family. The V-Class shall be the family's home. The aim is to use the Turks distinct commitment to the family (Sassy, 2008, p. 38).

Also Ay Yildiz applies a customer-friendly approach when addressing its Turkish clients. In October 2005, the company was founded as Germany's first mobile phone brand for the Turkish community and is 100 percent owned by the parent company E-Plus Group. In 2011, Ay Yildiz started an ethnic marketing campaign aimed at German-Turks. The campaign featured short bilingual spots (7 seconds) showing several German-Turks in their everyday lives. The spots were broadcasted on German private channels (including Kabel 1, Pro Sieben and Dmax). Longer versions (30 seconds) were broadcasted on the Turkish TV channels Kanal D, ATV, Show TV, Star, S TV, Kanal 7 and online in their full length of 70 seconds. Additionally, outdoor advertising introduced Ay Yildiz's new tariff named Aystar. According to the company's marketing director Rahsan Rabiye Ercan, the aim is to position Ay Yildiz as a mobile phone brand for the Turkish community in Germany and to portray the lifestyle of the German-Turks in Germany who share both cultures (Herrmann, 2011).

According to experts, Otelo (today: Arcor) had one of the most successful advertising campaigns for Turks. In the late 1990s, the company managed to contract about one third of all Turkish households within a few weeks. Almost every fifth Otelo client was a Turk. The company promised to plant a tree in Turkish erosion-prone regions for every new customer. 
The "Otelo forest" of 22.000 trees, about 200 kilometres from Antalya, made Otelo the first German company to win the Turkish Environment Award. The corresponding TV spot showed a famous Turkish actor strolling through the woods and musing about roots, home, nature and patriarchal authority. This campaign went into the heart of German Turks as it gave them the feeling: We can do something for our country (Sassy, 2008, p. 39).

However, not all ethnic marketing campaigns go into the heart of its target group. A common mistake represents the pure translation of the campaign in the respective language, without taking the target group's customs and habits into account. For instance, the former telephone company TelDaFax placed ads with the slogan "Kein Schwein ruft mich an" (literally translated as "No pig calls me", a German expression for "No one ever calls"). This shocked the Turks because in Turkish culture pigs are regarded as dirty and unclean animals. In December 2000, the ads of Siemens that have been shown in Turkish newspapers also have been met with a shake of the head. The company wished all Turkish citizens a Merry Christmas, although the majority of the German-Turks are Muslims that do not celebrate Christian holidays (Sassy, 2008, p. 39).

Also, the example of the Dutch telecommunications provider KPN shows the importance of a detailed analysis when penetrating ethnic target groups. In order to address the Turkish population, the company released phone cards with a picture of Mustafa Kemal Ataturk ${ }^{1}$ being unaware of the fact that a large group of Kurdish are among the "official" Turkish.

Figure 1: Dutch phone card

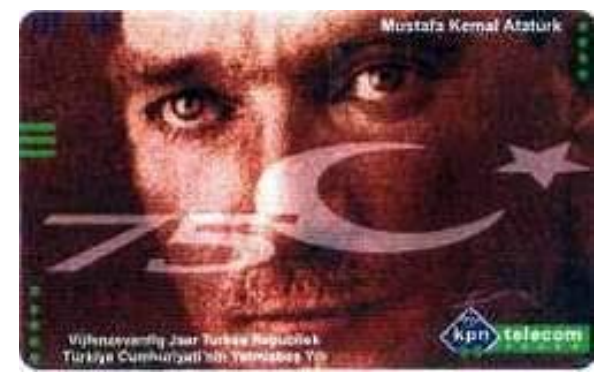

Source: Turkcards.com, n.d.

This issue was caused by language problems and the challenge to identify Turkish names from other, Arabians. Nowadays, a family name does not clearly show the origin of a consumer. Non-native Turkish which concern themselves with this issue will probably confound the names and origin as the table below shows.

\footnotetext{
${ }^{1}$ Mustafa Kemal Ataturk (Father of the Turks), founder and first president of the Turkish Republic, was responsible for the death of many Kurdish citizens during his reign.
} 
Figure 2: Examples of names of different origin

\begin{tabular}{lll}
\hline Name & Surname & Origin \\
\hline Süleyman & Kara & Turkey \\
Ahmed & Felaifal & Arabia \\
Sabriye & Alkan & Turkey \\
Sabriye & Kukaj & Kosovo \\
Bayram & Kilic & Turkey \\
Bajram & Alisic & Kosovo \\
Helmut & Zaczek & Germany \\
\hline
\end{tabular}

Source: Kleinbrahm, 2007

The above-mentioned positive and negative examples clearly show how important it is for companies to check the effectiveness of their common marketing activities with regard to addressing foreign audiences in their own country and to find new and individual ways of successful customer acquisition.

\section{HOW TO GENERATE BENEFIT WHEN ADDRESSING ETHNIC GROUPS}

In order to address a population with a different cultural background, it is necessary to build cross-cultural teams which are able to generate synergies - both on a cultural and strategic level (Zeng, 2010, p. 2626). To enable cooperation within ethno marketing teams and third party teams it is obligatory to implement adequate coaching related to the Turkish culture. In addition, it is recommended to employ expatriates as team leaders which lived in Turkey and therefore have the possibility to internalize the cultural differences. Thus, they are able to address tasks adequately and take potential risks and arguments into consideration with the aim of avoiding them.

\subsection{Marketing planning}

Compared with KPN, the German cell-phone operator E-Plus implemented a more sophisticated campaign. The company employed a Turkish team of marketing professionals which were able to point out the characteristics clearly, avoiding cultural and language related risks.

Figure 3: Turkish advertisement of E-Plus

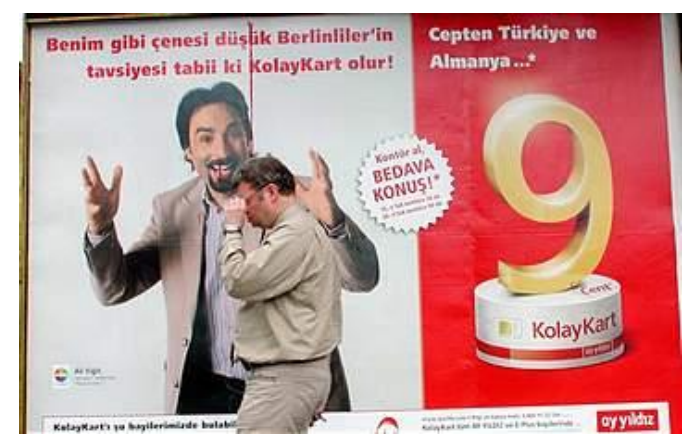

Source: Morgenpost.de, 2007 
Another important indicator of the marketing process which needs to be considered is the adequate planning of the distribution policy - the design of the point of sale. Once the operating company is aware of the fact that Turkish customers prefer to be consulted in their mother tongue it is recommended to employ those for generating optimized profit through the sales team. Moreover, the atmospheric design of the point of sale might communicate a warm, welcoming feeling of "feeling home" and hospitality. Having a look at the current design of the majority of German shops it can be stated, that currently there is hardly any specialized service. Another so-called "instrument" to achieve enhanced customer relations is the obligatory welcome drink customers get at barber shops, car retailers and a few boutiques. To meet the expectations of the Turkish target group it is recommended to offer non-alcoholic beverages such as tea or Turkish coffee, since the majority of the Turkish shares the Islamic religion (Seggie, 2011, p. 27).

\subsection{Marketing communications}

In the visual as well as language related design of advertising the facts of the target group analysis must be taken into consideration meticulously. The variety of different symbols and religious or political pictures is almost unmanageable for advertising companies. Thus, it is of high importance to conduct a precise analysis of the cultural conditions and customs and their subtle use and to consider the different meanings these have in varying cultures (Wilken, 2004, p. 34). These interpretations have impact on diverse, political communication attributes. This must be considered in the development of advertisements as well as in the design of packaging.

While the symbol of a cross is of rather limited importance in Western countries, this may result in negative associations and charges of proselytizing, particularly in Arabic countries. For some companies, this led to unexpectedly large effects, as the example of Carlsberg shows: the Danish company had to add a third elephant on the labels of its products sold in Africa, since only two elephants are considered as a "bad omen" (Usunier \& Walliser, 1993, p. 100). Especially in Turkish culture, the use of animals in advertisements is difficult to apply, as dogs are considered as generally frowned upon and pigs are seen as "unclean" animals (Wieschowski, 2007). Therefore, In the design of low-risk as possible advertisements and packaging should therefore be no religious symbolism or use of animals. The "safest" design in an advertisement for the Turkish audience in Germany thus implies for uninformed businesses.

\subsection{Ethnically-related humor}

This part deals with the integration of culture-specific humor in the promotion activities of advertising companies. However, it does not deal with common Turkish humor, but rather demonstrates by examples how typical German experiences are processed in a humorous way and arouse amusement and a familiar feeling among the viewers. An advertising campaign that was well accepted among the Turkish was the radio campaign of the GermanTurkish radio station Metropol FM, using the claim "Gehen Sie den Türken auf den Sender". The literal translation would be "Go on the Turkish's nerves" (Schmitt-Fink, 2007), but can be also perceived as "Listen to the Turkish radio". Rather mundane, but not less successful was the campaign of the German electronic goods merchant Media Markt that advertised its products in the Turkish language, read out by a German native speaker. The unusual sight and the sound of broken Turkish led to large sympathies among listeners and reminded many Turkish (especially the first generation of immigrants) of typical German style authorities. Also, the Fiat Doblo advertising was designed to be particularly humorous as the benefits of the vehicle were presented in a German authorities manner which parallels previous visits to administration offices. 


\subsection{Media planning}

Commercials in native Turkish media can generate a positive halo effect, since they show a company's appreciation of the target group. With regard to this, culture-specific humor is a good chance to break the ice between German and Turkish brands. The retailer Media Markt advertised its products in the Turkish language (Turkish TV channels) but spoken by a German, in a strict, "Teutonic" way. This campaign was very successful as it reminded the first and second generation of immigrants of their experiences with the German bureaucracy (Seidel, 2008).

\section{CONCLUSION}

The ethnic group of the Turkish plays an important role in the German economy with tendency to rise due to the growing number of the Turks preferring to purchase branded quality goods made in Germany. Furthermore, both a solid average household income and the high amount of cash capital combined with a low savings rate results in a rather high consumer spending and holds a strong potential especially for companies operating in the consumer goods market. Still, there is a lack of activity to service this segment in a more proactive way.

To turn the potential and chances into benefits, companies need to be aware of further factors. Although the preference of German brands might be high the Turkish hold a high preference for sales consulting in the Turkish language, especially regarding highinvolvement goods and services. This preference for the mother tongue can be also observed in this target group's great interest in native media. Here, ethnic marketing campaigns can use Turkish media and build on the importance of the Turkish inheritance which is part of the core values of the extended family network.

Despite these chances it needs to be stated, that setting up marketing teams which are solely focused on one ethnic target group is very expensive and is only an option for larger companies. Smaller ones which would like to benefit from the chances mentioned above are recommended to invest in external consultants to avoid serious mistakes such as KPN's Ataturk card. In addition, highly specialized sales forces and a new design of the point of sale in relevant geographic markets (such as urban districts) is cost intensive as well. Furthermore, the authors share the opinion, that not every product should be marketed with a strong ethnic focus, since the original positioning and differentiation as well as the brand value might be weakened and diluted. Also, ethnic marketing needs to be implemented reasonably for target groups of worthwhile potential and size. Setting up a marketing team for penetrating the Sudanese population for instance will hardly pay off, since their number is hardly measureable and their monetary potential is negligible. Nevertheless, it needs to be stated that a certain degree of orientation towards ethnic target groups needs to be focused by every company which aims for sustainable success in the German automotive and telecommunications industries.

"Multiculturalism is not a concept; it is a matter of fact."

Süssmuth, Rita, German politician, *1937

\section{REFERENCES}

Bertram, J. (2006) Ethnische Segregation in Deutschland - freiwillig oder erzwungen?, Paper, Carl von Ossietzky University Oldenburg.

BMW Germany (2015) Home [Online]. Available from: http://www.bmw.de/de/home.html (Accessed: 23 January 2015).

Cicek, N. (2010) Ethnomarketing for libraries - by the example of the Turkish speaking community. Stuttgart: Hochschule der Medien. 
Erdem, K. \& Schmidt, R. (2008) 'Ethnic marketing for Turks in Germany', International Journal of Retail \& Distribution Management, 36 (3), pp. 212-223, Business Source Complete [Online]. Available from: http://dx.doi.org/10.1108/09590550810859169 (Accessed: 27 August 2014).

Federal Office for Migration and Refugees (2013) Migrationsbericht 2011, 2013, [Online] http://www.bamf.de/SharedDocs/Anlagen/DE/Publikationen/Migrationsberichte/migrationsberich t-2011.pdf? blob=publicationFile (Accessed on $28^{\text {th }}$ January 2015)

Focus (2006) [Online]. Regulierung Available from: http://www.focus.de/finanzen/news/regulierung aid 114559.html (Accessed: 06 April 2011).

German-Turkish News (2013) Ethno-Marketing: Deutsch-Türken sind gute Unternehmer und konsumfreudig [Online]. Available from: http://www.deutsch-tuerkischenachrichten.de/2013/05/475004/ethno-marketing-deutsch-tuerken-sind-gute-unternehmer-undkonsumfreudig/ (Accessed: 23 January 2015).

Herrmann, S. (2011) Ay Yildiz: Bundesweite Kampagne für deutsch-türkische Mobilfunkmarke [Online]. Available from: http://www.wuv.de/marketing/ ay yildiz bundesweite kampagne fuer deutsch tuerkische mobilfunkmarke (Accessed: 28 January 2015).

Kleinbrahm, J. (2007) Das „Who is Who“ im Ethno-Marketing [Online]. Available from: http://www.address-solution.de/download/as adressen.pdf (Accessed: 22 January 2015).

Mead, R., Andrews, T.G. (2009) International Management. $4^{\text {th }}$ ed. Chichester: John Wiley \& Sons.

Reinnarth, J. (2007) Neue Zielgruppen in Deutschland - Wie Ethno-Marketing gezielt ausländische Mitbürger anspricht [Online]. Available from: http://www.pressrelations.de/NEW/standard/result main.cfm?pfach=1\&n firmanr $=117782 \&$ sek

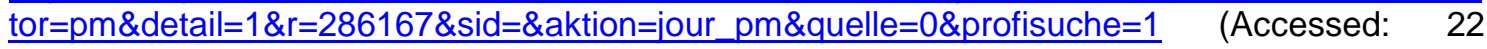
January 2015).

Sassy, A. (2008) Ethno-Marketing im Sozialwesen: Konzept für ein Projekt der kultursensible Altenpflege (thesis), Beuth Hochschule für Technik.

Schmitt-Fink, E. (2007) Ethnomarketing in Deutschland [Online]. Available from: http://www.migrationboell.de/web/integration/47 1101.asp (Accessed: 05 April 2011).

Schroeder, D. (2007) Lebensmittel für Muslime: Mit Allah an der Fleischtheke [Online]. Available from: http://www.spiegel.de/wirtschaft/unternehmen/0,1518,651441,00.html (Accessed: 22 January 2015).

Seggie, F. N. (2011) Religion and State in Turkish Universities. Houndmills-Basingstoke: Palgrave Macmillan.

Seidel H. (2008) Ethnomarketing: Warum deutsche Firmen auf Türkisch werben [Online]. Available from: $\quad$ http://www.welt.de/wirtschaft/article1597874/Warum-deutsche-Firmen-auf-Tuerkischwerben.html (Accessed: 22 January 2015).

Struening, F. (2012) Türken in Deutschland 2012 [Online]. Available from: http://www.citizentimes.eu/2012/08/19/turken-in-deutschland-2012/\#note-7448-9 (Accessed: 22 January 2015).

Turkcards.com (n.d.) Holland [Online]. Available from: http://www.turkcards.com/for/holland-01.jpg (Accessed: 22 January 2015).

Usunier, J.-C. \& Walliser, B. (1993) Interkulturelles Marketing: Mehr Erfolg im internationalen Geschäft. Chichester: Gabler.

Wieschowski, S. (2007) Hunde verpönt, Nackte verboten [Online]. Available from: http://www.tagesspiegel.de/wirtschaft/hunde-verpoent-nackte-verboten/837688.html (Accessed: 22 January 2015).

Wilken, M. (2004) Ethno-Marketing: Erfolgreiches Marketing für eine multikulturelle Gesellschaft. Düsseldorf: VDM Verlag.

Winkelhage (2009) Mobilfunkmarkt [Online]. Available from: http://www.faz.net/s/RubB3C76B7D0C6444579C67AF441E2ECB6D/Doc E681E1BB87F24456 4B7D6CFC60829234A ATpl Ecommon Scontent.html (Accessed: 05 April 2011). 
Zeng, S. X. (2010) 'Creating synergy for cross-cultural teams in international R\&D projects', African Journal of Business Management, 4 (13), October, pp. 2625-2633, Social Sciences Citation Index [Online]. Available from: http://search.ebscohost.com.ezproxy.liv.ac.uk/

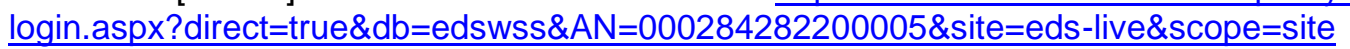
(Accessed: 22 January 2015). 